\title{
Modernisation of Social Conscience: Topical Problems of Literary Local Lore
}

\author{
Zinulla Z. Mutiyev, ${ }^{+*}$ Aidarbek A. Akbulatov, $^{\dagger}$ Marat K. Azhgaliyev, ${ }^{\prime}$ Rita B. Sultangaliyeva ${ }^{\dagger}$ and
} Bakytgul E. Shagimgereyeva'

\begin{abstract}
Literary study of local lore is a specific area of knowledge about the history of literature, which is distinct in a special selection of material, and an aspect of its consideration. Local lore contributes to the learning of historical, cultural, geographical peculiarities of a particular territory. This paper deals with the issues of local lore. The research of the artistic heritage of poets and writers of the Cis-Ural Region, West-Kazakh District is one of the topical problems of contemporary literature. In this paper, the works of the Russian poets are discussed considering the writers of the 20th - early 21st centuries, such as A.S. Pushkin, V.I. Dahl, M.A. Sholokhov and the great Tatar poet Gabdulla Tuqay. It has been established that the best of Gabdulla's works, included in the gold reserves of the Tartar literature, was written in the town of Uralsk. It has also been established that the poets and writers of the Cis-Ural Region contributed new genres to the literature, namely prose and drama. The study of cultural and spiritual ties with kindred Turkic-speaking peoples today is one of the priorities of the Kazakh literary criticism. At the same time, the authors have found the following ways of solution of such tasks: the introduction of the "Literary Local Lore" elective course to the study process of secondary and high schools, writing of monographs, and compilation of anthologies. The paper will be useful for teaching the subject of "Literary Regional Studies" because the course based on the cognitive material, which considers and propagates the development and prosperity of the national fictional literature, as well as its investigation from a scientific point of view and transmission of the values to the younger generation.
\end{abstract}

Keywords: Spiritual Renaissance, Cis-Ural Region, Poets-Writers, Artistic Heritage, Literature Works.

\footnotetext{
${ }^{\dagger}$ Department of Kazakh Philology, M. Utemissov West Kazakhstan State University, 090000, 162 Dostyk Ave., Uralsk, Republic of Kazakhstan

*Corresponding Author, Email: zinulla_mutiev@mail.ru

${ }^{1}$ Departmentof Pedagogy, University of Innovation and Technology of Western Kazakhstan, 090000, 12 G. Karash Str., Uralsk, Republic of Kazakhstan

'̄Department of Russian Philology, M. Utemissov West Kazakhstan State University, 090000, 162 Dostyk Ave., Uralsk, Republic of Kazakhstan

(C) 2018 Mutiyev et al. This is an Open Access article distributed under the terms of the Creative Commons Attribution License (http://creativecommons.org/licenses/by/2.0), which permits unrestricted use, distribution, and reproduction in any medium, provided the original work is properly cited.
} 


\section{Introduction}

Our homeland, the Kazakh Republic, due to its location spanning both Europe and Asia in one latitude is among the countries with simultaneously developing economy and culture (Silagadze, 2018). Kazakhstan has all the four sides - East and West, North and South, which reflects immensity. Besides, our country with its peculiar traditions and customs is distinct in the richness of the fiction literature. The folklore itself, the heritage of the oral folk art, apart from the traditional literature, comprises one hundred volumes (Azybaeva, 2014; Ibraev et al., 2009).

If the Kazakh fiction literature is a united system of the Kazakh people's spiritual culture, so it is undoubtedly based on the literature of the region. Thus, due to the research of the local lore and its recovery, the solution of the spiritual renaissance problems, pointed by the Head of the State, is possible (Nazarbayev, 2017).

The President of the Republic of Kazakhstan Nursultan Nazarbayev in his article has been focused on the problem of the national identity renaissance. He highlighted that "the national customs, native language, music, literary heritage, which are the national spirit and identity, must stay in our mind forever. The ancestor's legacy passed down through the generations is just a page of our incredibly rich culture (Nazarbayev, 2017).

The history of the Cis-Ural Region starts from the ancient times. Lyrical epos "Kuz Zhibek", the poetry of the $15^{\text {th }}-17^{\text {th }}$ centuries, the literature of the khan's period, Shcernyjaz, Almazhan Azamatkyzy (19 ${ }^{\text {th }}$ century) are at the headwaters of the literary Cis-Ural Region.

Investigation of the local lore literature of West Kazakhstan helps to define the main direction of the Cis-Ural Region poets and writers' heritage. The investigation of the poets and writers' works (prose, poetry, drama etc.), published at the $20^{\text {th }}$ - early $21^{\text {st }}$ centuries, their analysis from the literary-scientific point of view, and their systematisation is one of the main goals of contemporary Kazakh literature.
The results of the research tocause the necessity to publish the "Local lore literature" monography in three books, presented by stages, and also to compile the anthology. One of the main problems is to introduce the "Local lore literature" elective course to the process of study of universities and schools and to develop its program. Enrichment of the education with the help of the course, and development of intelligent, mentally rich people loving their country is one of the topical problems of the literary education.

\section{Role of the Literary Local Lore Material in the Educational System}

Investigation of Literary Local Lore meets the basic requirements of social identity modernisation (Bondaletov, 2015; Kozyrev et al., 2016). Effectiveness of literary lore investigation in the system of universities and schools lie in the following: students, namely, readers as a component of the general Kazakh literature by getting acquainted with the content of the literary material of a particular region or district, get acquainted with the spiritual, cultural sides of life; observe the peculiarities of language connected with the local life, and the literary language norms; become able to get acquainted with the world of famous people's images, historical persons, which became the prototypes for creation of fiction works.

In case of introduction of "Literary Local-Lore" in the future to the universities and schools as an elective course, it will provide a great opportunity for studying the Literary Local Lore of our region.

As a result of the "Literary Local Lore" course (discipline) implementation, the following tasks may be solved:

- Task 1: providing the students with the opportunity to get acquainted more deeply with the heritage of writers and poets of the Cis-Ural Region of the $20^{\text {th }}$ century and the first twenty years of the $21^{\text {st }}$ century.

- Task 2: investigation and analysis of life and work of such great representatives 
of the West Region as Sh. Bukeev (18471920), a creative person of the national freedom-loving nature, G. Karash (18751921), a prominent representative of the Kazakh Soviet literature, poet Kh. Otegalyieva (1889-1984),

A.

Zhumagaliev (1915-1942), whose fiery verses helped to raise the national spirit of the fighters in the Great Patriotic War and who died on the battlefield.

- Task 3: analysis of the prominent novelists' after-the-World-War-II period works, such as K. Zhumaliev (19071968), T. Zharokov (1908-1965), X. Yesendjanov (1908-1975), Zh. Tlekov (1911-1980), S. Seitov (1917-2007), Zh. Moldagaliev (1920-1989), and B. Amanshyn (1924-1985);

- Task 4: getting acquainted with the creative works of such poets and writers, who brought the new vision to the Kazakh 1960-1980s literature, such as B. Yrzabaev (1932-1995), K. Myrza Ali (1935-2011), S. Yerkebaev (1935-1997),

S. Daumov (1935-2004), Zh. Nabiullin (1936-2012), K. Beckturganov (19372015), K. Zhumagaliev (1937-2013), B. Oyshibaev

(1940-1997),

A. Narikov(1940), A. Sultanov (19422003), K. Karamanuly (1943), A. Backtyrgeeva (1944), M. Yesmalagiev (1946-2004), P. Abdulagiev (1948-1984), and A. Beckturganov (1948);

- Task 5: making a monography analysis of the 1980-1990s poets, writers and innovators, such as A. Kadyrbaev (1950), B. Baymukankyzy (1956-2007), A. Shakhin (1954), Z. Sysengali (1957), G. Seytack (1958), A. Taubaeva (19582016), U. Sarieva (1957), and Serikhali Hassan (1960);

- Task 6: analysis of the works of the next representatives of the Independence period literature: T. Taymasuly, (1965), A Seytack, (1966), M. Shuyshnaliev (1967), B. Gubaidullin (1965), B. Aytbolatuly (1972), M. Balmond (1972), B. Khaliolla (1979), and T. Mycky (1988);
- Task 7: publishing an annual literature anthology based on the best works of poets and writers of the Cis-Ural Region.

- Task 8: developing the program of the "Literary Local Lore: Spiritual Renaissance" elective course.

\section{Characteristic of National Literature Renaissance}

Considering the history of the development of the world literature and its connection with the Kazakh literature, one may notice that the travellers that visited the Kazakh steppe in the past centuries and paid attention to the richness and eloquence of the Kazakh language and the literature were very impressed. From the first quarter of the $19^{\text {th }}$ century, travellers and scientific ethnographers started to appear in the Kazakh steppe. The scientists investigate the spiritual richness of the nation with great interest. For example, an investigator of the Turkic peoples' folklore V. Radlov wrote, "A Kazakh is such a master of the word that he not only can produce long verse improvisations, but his ordinary speech has a certain rhythm in the construction of phrases and periods, so that it often sounds like poetry" (Radlov, 1870: 17).

Taking into consideration the conclusions made by famous scientists of the Turkic word, the authors concluded that the poem is the basis of the general system of poetic thinking, and comprises the national identity. Scientists and investigators of nomads' culture must take into consideration the following words said by M.P. Melioransky, "The Kazakh language is considered as the richest, cleanest language among the Turkic languages.." (Melioransky, 1905) and L. Grzhebycheck, "Your language is abundant in synonyms" (Grzhebichek, 1970: 18) as high evaluation given to the art of word, oral speech, and folklore of the Kazakh people.

Grigory Potanyn, a friend of a first Kazakh scientist, Sh. Ualikhanov, being impressed with the art of word of the Kazakh people, wrote about the high level of the Kazakh poetic art (Zhubanov, 2002).

The improvisation skills of the aqyns, the skillful mastery of the Kazakh people's in Aytysh (a 
song competition held between two aqyns), is described by a talented son of Kazakh steppe Ch. Valykhanov, who at the same time notes that this type of art may also be observed among the Arab people (Yalochanov, 1985).

Considering the issue on the connection of the national literature renaissance with the national literature and the national code and the origin, it is necessary to take into account the connections within the literature of the Turkic people. The works of E.E. Bertels, A.N. Samoilovich, S.E. Malov, A.N. Hazhyp had significant value for development of Turkology. At the same time, prominent scientists among the Kazakh people, such as Sh. Ualikhanov, A, Baytursynov, R. Seyfullin, M. Auezov, R. Mukanov, E. Ysmailov, S. Amanzholov, $M$, Gabdullin, A, Margulan, R, Berdibaev, A. Kekilbayev, M. Zholdasbeckov, Kh. Suynshaliev, S. Kaskabasov, G. Musabaev, K. Omiraliev, M. Tomanov, A. Yegeybaev, N, Kelimbetov, T, Tebegenov, and others contributed to the general development of the Turkic peoples' heritage.

The research scientist of the Turkic people literature N. Kelimbethov in his work shows that all the different tribes occupying the great territory of Turkic Kaganat had the common language understandable for them all. (Kelimbetov, 1991).

Making a great contribution to the investigation of the ancient Turkic written monuments, Turkologists V. Tomsen, V.V. Radlov, S.E. Malov laid the basis for the investigation of Turkology as a science, which is a starting point for the literary-spiritual renaissance today. In this case, the role of the world-famous 10-volume work "Samples of Folk Literature of Turkic Tribes" is tremendous, which is considered to be the set of fundamental investigations of $\mathrm{V}$. Radlov and is greatly important within the research of Turkology (Smailovich, 1992).

The talented scientist, a friend of the Kazakh people V.V.Radlov, having gathered and systematized the rich heritage of the Turkic folk, published it in several volumes and translated into the European languages. As for the gathered material, V.V. Radlov wrote, "Having started the investigation of the Turkic adverbs of my native Altay Region in 1859, from the very beginning I started to gather not only the works of the folk art but the also the great lexical material" (Radlov, 1988).

Considering the literary life of the Cis-Ural Region, the important place is taken by the connection with the Russian-Kazakh literature. In the rich and deep history of Uralsk, the regional centre, the connection of the literature with the culture is strong.

The Cis-Ural Region is a place, where many pages were written by the prominent representatives of the Russian literature and art - I. A. Krylov, V.A. Zhukovsky, A.S. Pushkin, V. I, Dahl, A.N. Plesheev, T.G. Shevchenko, L.N. Tolstoy, V.G. Korolenko, D.A. Furmanov, A.A. Fadev, K.A. Fedin, M.A. Sholkhov, V.V. Bianki, and A.P. Gaydar.

\section{Peculiarities of Development of Pushkin's Creative Works in Kazakhstan}

There is no need to introduce A.S. Pushkin in Kazakhstan - here, in each house his works are highly evaluated alongside with the works of Abay. The great writer tied his creative work with Kazakhstan and the Kazakh people as far back as he was alive.

Having decided to write about the rebellion of the Russian peasants led by Yemelyan Pugachev, on August 17, 1833, A.S. Pushkin went from St. Petersburg to the places, where this historical event had taken place. He passed Moscow, Nizhni Novgorod, Kazan, Symbirsk, and on the $18^{\text {th }}$ of September, he came to Orenburg. Here he stayed for two days. He left Orenburg on the $20^{\text {th }}$ of September; the next day he was in the city of Uralsk, where he stayed for three days, and on the $23^{\text {rd }}$ of September, he went to Boldino. Today, in memory of these historical days, there is a memorial tablet on the wall of the house, where the poet lived during his travel.

When Pushkin was in Uralsk, he walked a lot along the bank of the Zhaika (Ural) River. Here he gathered the historical data, studied the archive materials, and visited the sites, where 
the rebellions had taken place. He wrote down the memories of the eyewitnesses of the rebellion, the stories, and legends survived within the folk. It gave Pushkin a great opportunity to show the historical truth about the peasant rebellion, as well as about its leader. The author also showed that among the Russian peasants there were the representatives of other nationalities - Bashkirs and Kazakhs. In a letter to his wife Natalia Nikolayevna, Pushkin wrote that in Uralsk people had welcomed him with open arms, he had noted the hospitability of this folk.

It is known that during his stay in Orenburg the poet spent time with the folklore-writer V.I. Dahl. He was a friend of Pushkin, one of those, who were by his side in the last hours of the poet's life. If to learn the creative works of Pushkin systematically, one may see what the data about the Kazakh people take a great place here, his warm attitude to this folk, and the patterns of friendly relations between the two folks during the entire $19^{\text {th }}$ century.

Being the patriot of his country, Pushkin simultaneously studied the life of the two related folks with similar destiny and deeply understood their desires and interests. While being in the Kazakh Region, in Orenburg and Uralsk, he showed great respect to the local people, paid attention to their life, customs, and culture. Pushkin looked beyond the Pugachev's participation in the rebellion of the Kazakh Dzhigits, at the same time he was focused on the rich art of the Kazakh's word, wrote down one of the most valuable works of the oral lore - poetry "Kozy Korpesh - Bayan Sulu". This manuscript of 5 pages, written in ink, became known to the investigators of Pushkin's heritage later. It was published to the $100^{\text {th }}$ anniversary of the poet. The $3^{\text {rd }}$ volume of edition "Chronicle of Pushkin's Commission" contained the article "Manuscript of the Kazakh legend from Pushkin's archive" by professor L.B. Modzalevsky, where the author highlighted that Pushkin had been acquainted with one of the most significant memorials of the Kazakh people.
The manuscript found in the archive of Pushkin is one of the first materials about the Kazakh poetry in the Russian language and the Oriental studies.

Some peculiarities of "Kozy Korpesh - Bayan Sulu" preserved in Pushkin's archive enriched the Kazakh legend with warm, romantic notes. In one of the variants of the preserved manuscript of poem "Exegi monumentum" written not long before the death, the poet has mentioned the Kazakh people (here by "steppe wise" the word "Kazakh" is meant). So the third stanza sounds in the following way:

A word 'bout me will spread all over great Rus'

Moreover, any tongue will voice my name in it

A proud Slavic son, a Finn, a yet so wild Tungus

Moreover, steppe wise and old Kalmyk

Pushkin wrote this poem three years after his stay in Uralsk. In 1999, in Moscow, within the celebration of the $200^{\text {th }}$ anniversary of the great poet, the full compilation of his draft manuscripts was published. It is known that Chokan Valikhanov, Ibray Altynsaryn and Abay Kunanbayev were the first in the Kazakh history, who produced the interest for Pushkin's heritage. In St. Peterburg, in the house at the Moyka River Embankment, where Pushkin lived last months of his life, the manuscript of the legend is preserved. Kazakh poets - Zhabaev, Ormanov, Bekhozhyn, Moldagalyev, Satybaldyn - wrote a number of poems about this great poet. Today, in the cities of Almaty and Uralsk, there are memorials to the poet. The house, where Pushkin lived in Uralsk, is currently a museum; many educational institutions and schools, libraries and streets of Kazakhstan are named after Pushkin.

\section{Creative Work of Dahl and Sholokhov}

In the history of life and creative work of the Kazakh people of the first half of the $19^{\text {th }}$ century, a particular place is taken by one of the most prominent representatives of the 
Russian culture V.I. Dahl, who during 18331841 worked as an officer in Orenburg and Uralsk, and often visited Kazakh auls. V.I. Dahl was very interested in the life of simple nomadic people. In one of his letters, he wrote, "I live as a nomadic again. Here it is so good that I will never leave this place." Dahl started to investigate the customs, traditions, Kazakh values, thanks to which many valuable materials became known.

In 1839-1840, V. Dahl took part in the Khivan campaign with the Russian Army. He also took care of the leaders of the rebellion in 1836 1938 Isatay Taymanuly and Mahambeth Utemisov. In the short novel "Bikey and Maulyana" V. Dahl depicted the Kazakh's life in the Orenburg Cis-Ural Region. In this story with the great artist mastery the author describes honestly and warm-heartedly dzigit Bekey, his friendly relationship with Russians, his rude father, his fight with feudal lord Esengeld and insidious brother Zhankushik. The especially great impression is made by the fight between the son and the father not allowing his son to marry his beloved and the dzigit's death. In 1845 , the story "Bikey and Maulyana" was published in the French language in Paris. The European readers know about the Kazakh people thanks to this work. He also depicts the Kazakh life in such stories as "Mayra", "Night Watchman", which were highly estimated by Belinsky and Turgenev.

In his letters and articles, Dahl is particularly interested in the richness of the oral lore creative works and points to the similarity between the Kazakh and Russian characters. In his article "Tatarshyldyk" he exposes the Tsar's officers. Dahl took part in the research about the Kazakh steppe from the scientific point of view, helping to organize the first local-lore Museum in Orenburg.

The Justice of Dahl in the solution of the territory strives between families, protection of the Kazakh women from the custom of levirate, and warm attitude to aqyns raised his authority in the eyes of simple Kazakhs. In one of the statements to the Orenburg governor, Isatay Taymanov asked to authorize Dahl to investigate the dispute between him and Zhangyr khan. The governor, of course, refused this request.

The life of the great Russian writer, owner of the Nobel Prize M.A. Sholokhov is tightly connected with Uralsk. Some of the works were written in the cottage near Uralsk. In West Kazakhstan, there are many places, connected with the writer's name. It is known that in the years of the Great Patriotic War Sholokhov's family lived in the Daryinskoye Village of the Zelenovskyi District. Being a war correspondent in newspapers "Pravda", "Red Star" the writer often visited this place. Here he wrote his front essays and chapters of the novel "They Fight for their Country". And after the war, during almost 30 years Sholokhov and his family visited West Kazakhstan. It is noteworthy that the good news about the award of the Nobel Prize was received by Sholokhov in Kazakhstan. In Daryinsk Village, where Sholokhov stayed, the Memorial Museum is located with his belongings preserved. In 2002, in Uralsk, the memorial was established, and a street was named after the writer. There are many examples witnessing the extension of the Russian-Kazakh literary and cultural connections.

Having become independent, our country gets an opportunity to make more tight contacts with related nations. For the first time the work was published, which allows analyzing the general folklore heritage of the Turkic folks.

\section{Development of the Literary Local Lore in the Creative Works of G. Tuqay}

In the development of Literary Local Lore, it is very important to consider the problem of spiritual renaissance within the heritage of the Turkic folks. In the literature of the Cis-Ural Region, a great place is taken by the creative works of the great poet, a son of the Tatar nation - Gabdulla Tuqay (1886-1913). Having arrived in Uralsk, he studied in medrse Mutigia. The poems of Tuqay were firstly published in 1913 in the "Aikap" magazine No. 7. Since that time, the poet's heritage was published in the Kazakh language several times. Thus, in 1925, the poems of Tuqay translated by Zhakan 
Syzydykov were published as a special book. In 1952-1975, his poems and verses were published, and in 1962 - a special edition of "Shurale". In 1965- selected works, in 1966 poems for children. The papers and researches about the poet's creative works were written. Kazakh poets devoted their poems to Tuqay. So, Zh. Syzdykov wrote "Tyqay in Karabalyk", T. Alimkulov, - "Gabdulla Tuqay", G. Zhumabayev - "Tokai tergen әріптер" (translated as "Letters written by Tuqay"), I. Mambetov- poem “Тұңғыш Тоқай" (translated as "First Tuqay").

In 2002, in the Uralsk Museum "Old Uralsk", they opened the hall devoted to the Tatar poet G. Tuqay. Then, thanks to the initiative and hard work of the literature admirers in Uralsk, they renovated and rearranged to the museum the house of Tukhvatulliny. The local government and the ministry of culture in Tatarstan provided support and financial assistance for the new construction that was attached latter. The new building may be considered as a part of the centre administration.

Also, they organised there a small library, where the works of Tuqay and other samples of literature were gathered. There is a special hall for conducting different cultural events, evenings, competitions, which were organised with the participation the of museum's guests, students and schoolchildren. Even though the talented poet of the Tatar people Gabdulla Tuqay was born and died in Tatarstan, most of the investigators consider the small town of Kazakhstan Uralsk to be a spiritual homeland of the poet. Here he got his education, where he got acquainted with Pushkin's creative works, and here he imitating the great Russian poet, wrote his thoughtful works. It indicates the wisdom of young Tuqay, who was his trusted assistant. Not in vain at the beginning, serving as a typesetter, he became a chief editor for a short period. Here he also wrote, typed his poems and papers.

In general, according to the sources, the best works of Gabdulla Tuqay included into the gold reserves of the Tatar literature were written in Uralsk. Here he got acquainted with the children of the house owner - Galia and Kamil. Later, Galiya Kaybitskaya got the title of the National artist of the RT, and her belongings were placed in the museum of Tuqay. It seems that the children from the Tukhvatullin's family were brave, and their photos are also placed on the house's walls. It is possible to know, where and how the talented son of the Tatar nation lived and worked while visiting the museum.

Representatives of the Tatar nationality communicating with the local Kazakhs learned their language, which demonstrates the depth of the roots of their literary and cultural relations. If a prominent Tatar writer G. Ibrahimov in his work of 1916 wrote, "Spiritual life of the Kazakh people is distinct in its peculiar natural authenticity", then a Tatar scientist A. Sagdi state, "If there is the cleanest, the richest language preserved in its pristine form, then it is the Kazakh language and the literature" (Sagdi, 1926: 25).

There is a historical connection between the town of Uralsk and the Cis-Ural Region and prominent Kazakh writers. Life and creative works of widely known writers - R. Seyfullin, Kh. Yesenzhanov, T. Zharokov, K. Amanzholov and others - standing at the origins of the local lore, are also connected with the town of Uralsk. So, a part of the works popular among the readers is written in this town. It means that the Cis-Ural Region may be considered as a starting point of their creative way.

\section{Peculiarities of Innovation in the Kazakh Literature}

When studying the origin of the Literary Local Lore, it would be correct to pay attention to the positive literary innovations of the creative heritage of the poets and writers of the Cis-Ural Region in the $20^{\text {th }}$ - early $21^{\text {st }}$ centuries. In the $20^{\text {th }}$ century, the Kazakh literature obtained such genres as prose and drama. Among the Kazakh writers adhering to the enlighteningdemocratic views, there were Shangerey Bokeev (1847-1920) and Gumar Karash (18751921). In their works, they expressed the public opinion, political and social problems, and reflected the picture of those times. However, in the Kazakh literature, the creative heritage of 
Sh. Bokeev and G, Karash is not fully investigated.

The 1940-50s is the period of formation and determination of the Kazakh literature direction. A prominent representative of that time, who combined Aytysh with (written) poetry, and named by people as "woman of aqyns" was Khalyma Otegalieva. As a preacher of a new life Kh. Otegalyeva reflected the life of a working man and the call for peaceful life in her lyrical works (Zharikbaev and Kaliev, 19912). At the same time, the fictional peculiarities of her poetical art are not yet considered in the national literary local lore.

One of the prominent poets, who became the victim of the fiery war years, is Abdolla Zhumagaliev(1915-1942). The disclosure of determination of the fictional lyric's identity problem, the investigation of the theme and ideal of the poet's prose combined the pen with the weapon, being an example of courage and honour is still waiting for its investigator.

If in the 1950-60s, in the Kazakh prose, the formation of the story and novel genres may be observed, then its further development was promoted by the prominent representatives of the regional literature, such as K. Zhumaliev (1907-1968), Kh. Esenzhanov (1908-1975), Zh. Tlekov (1911-1980), B. Amanshin (1924-1985). For example, a few people know that a literary scholar, an investigator of literature, academician K. Zhumaliev started his creative way as the author of poems and prosaic works (Zharikbaev and Kaliev, 1997).

Considering that the literary critics attribute the literature of the 1960-1970s and the 1970$1980 \mathrm{~s}$ to the period of renaissance, the following prominent representatives of that period as T. Zharokov (1908-1965), R. Seitov (1917-2007), Zh. Moldagaliev (1920-1989), K. Myrza Ali (1935-2011), S. Yerkebayev (19351997), S. Daumov (1935-2004), Zh. Nabiullin (1936-2012), K. Beckturganov (1937-2015), K. Zhumagaliev (1937-2013), K. Karamanuly (1943), A. Begtyrgeev (1944), M. Yesmagaliev (1946-2004), and S. Abdulagieva (1948-1984) should be considered as prominent writers, introduced innovations not only to the literary
Cis-Ural Region but to the Kazakh literature in general. Even though in the Kazakh literature their creative work is fully investigated, from the perspective of science and literature of the post-Soviet area, there are undisclosed sides of their literary activity. The necessity appears to investigate the local literary core in a new direction, to conduct the scientific-theoretical analysis within the spiritual renaissance.

Alongside with the acquisition of sovereignty of the government in culture and literature, there are positive changes, including the fact that the representatives of the region became braver in the choice of the topic of their works. If talented poets and writers famous in the Republic before this period, such as B. Oyshybaev (1940-1997), A. Narikov (1940), A. Sultanov (1942-2003), A. Beckturganov (1948), Sh. Kydyrniyazova (1949), A. Kadyrbayeva (1950), A. Shakhin (1954), B. Baymuckankyzy (1956-2007), G. Seitack (1958) were in constant search of the ideas, then $D$. Mushtanova (1954), Z. Sysengali (1957), Y. Sarieva (1957), A. Taubaeva (1958-2016), Serikali Hassan (1960), B. Gubaidullin (1965), T. Taymasuly (1965), A. Seitak (1966), M. Shuyinshalieva (1967), K. Kuttymuratuly (1970), B. Aytbolatuly (1972), M. Balmolda (1972), B. Haliolla (1979) and others are contributing to the development of the independent country literature, including the Literary Local Lore.

Providing the support to the creative youth standing at the origins of the spiritual renaissance of the Literary Local Lore is currently the topical problem of the Literary Local Lore.

\section{Conclusions}

Investigation of the cultural and spiritual connection with the native Turkic-speaking nationalities is currently one of the prioritised directions of the Kazakh literature. In particular, the translation of the Kazakh literary scholars' research of the literature of the Turkic-speaking nationalities to their languages (in particular, to Kyrgyz, Turkish, Tatar, Bashkirian and others) would undoubtedly provide the creation of closer contact with the native nations in the cultural and spiritual aspect. 
The question about the topicality of the study and the investigation of the "Literary Local Lore" course may be answered as follows:

First, studying "Literary Local Lore" is distinct in its topicality of additional enhanced education by the university students and schoolchildren;

Second, "Literary Local Lore", being in tight connection with the main studying programs, expands the boundaries of the humanitarian, educational system. The proposal to the young generation of a form of the spiritual renaissance of philological education provides bright future for the nation, as well as the establishment and inclusive development of the conscious generation;

Third, "Literary Local Lore", preserving the directions of the "Mangilik El" scientific bases may tobe required in the area of humanitarian education of the $21^{\text {st }}$ century. It meets the requirements in the solution of the problem of the national conscience renaissance mentioned in the article of strategical importance by $\mathrm{N}$. A. Nazarbayev, "The Course towards the Future: Modernisation of Kazakhstan's Identity";

Fourth, "Literary Local Lore" contributes to the upbringing of the young generation's national spirit, caring attitude to the native language and literature, history and culture;

Fifth, the Head of the State emphasises the upbringing of the new generation's national spirit and their learning, enhanced studying of the national values. In this regard, the governmental program reflects all the requirements to the comprehensive education with the consideration of the local peculiarities following the basis of the literary education. In the "Concept of the Literary Education" of the RK and "Concept of the Kazakh Literature
Teaching", considering the principles of the content renovation and the educational structure, conceptual directions and ways, and the scientific substantiation, it is highlighted that the content of the Kazakh literature subject should be based on the national values.

\section{References}

Azybaeva, В. (2014). Бабалар сөзі (Word from Ancestors). 100-volume series of Kazakh folklore. Astana: Foliant, pp. 33-49.

Bondaletov, A.A. (2015). Evolution of selforganization ideas. Sotsiologicheskie Issledovaniya, 3, 132-139.

Grzhebichek, L. (1970). Description of the Kyrgyz and Kaysaq Life. Saint-Petersburg: Publishing House of Imperial AS, p.18.

Ibraev, Sh., Bachadyrova, S., Rachymov, B. (2009). Folklore of the Turkic-Speaking Nation. Astana: Astsns Polygraphy, p. 432.

Kelimbetov, N. (1991). Literature of the Ancient World. Almaty: Foliant, pp. 37.

Kozyrev, M.S., Medvedeva, N.V., Maslikov, V.A., Frolova, E.V., Beljakov, B.L. (2016). The influence of the social structure on ideology in the works by R.K. Merton. Man in India, 96(10), 3581-3590.

Melioransky, M.P. (1905). The Legend of the Edige Manuscript. Saint-Petersburg: I. Boragansky Publishing Lithography, 1905, p. 86.

Nazarbayev, N.A. (2017). Course Towards the Future: Modernization of Kazakhstan's Identity. Kazahstanskaya Pravda, 70 (29051), pp. 2,18

Radlov, V.V. (1870). Samples of nat. lit. of Turkic tribes, Kazakh adverbs. Part III, Saint-Petersburg: Printing House of Imperial AS, pp. 17.

Radlov, V.V. (1988). Experience of a Dictionary of Turkic adverbs. Ed.1. Saint-Petersburg: Publ. House Imp. AS., pp. 3-4 
Sagdi, A. (1926). Language, Literature, Writing and its Historical Development. Kazan: Tatgoizdat, pp. 86.

Silagadze, A. (2018). Some aspects of economic ideas in Shota Rustaveli's "the knight in the panther skin". Bulletin of the Georgian National Academy of Sciences, 12(1), 161167.

Smailovich, A.N. (1992). Radlov as a Turkologist. New East, 2, pp. 708.

Yalochanov, Sh. Sh. (1985). Elected. 2-edition. Almaty: Zhzyshi, pp. 193-194.

Zharikbaev, K., Kaliev, S. (1992). The Concept of Literary Education. Almaty: Rayan, p. 21.

Zharikbaev, K., Kaliev, S. (1997). The Concept of Literature Teaching. Almaty: Rayan, p. 23.
Zhubanov, A.K. (2002). Nightingale of Centuries: Essays about National Compositors and Singers. Translated from the Kazakh language by G. Belger, Almaty: Dayk-Press, p. 110.

\section{Acknowledgements}

This research is a part of the grant project of the Committee of Science, the Ministry of Education and Science of the Kazakh Republic No. AP05135443 "Literary Local Lore: Spiritual Renaissance (Creative Heritage of the Cis-Ural Region of the $20^{\text {th }}$ - early $21^{\text {st }}$ century)". We are highly grateful to the funding agency. 